University of Nebraska - Lincoln

DigitalCommons@University of Nebraska - Lincoln

Faculty Papers and Publications in Animal

Science

Animal Science Department

4-4-1993

\title{
Correlations for Genetic Expression for Growth of Calves of Hereford and Angus Dams Using a Multivariate Animal Model
}

\author{
R. Nunez-Dominguez \\ University of Nebraska-Lincoln, rafael.nunez@correo.chapingo.mx \\ L. Dale Van Vleck \\ University of Nebraska-Lincoln, dvan-vleck1@unl.edu \\ K. G. Boldman \\ University of Nebraska-Lincoln \\ Larry V. Cundiff \\ University of Nebraska-Lincoln, Icundiff2@unl.edu
}

Follow this and additional works at: https://digitalcommons.unl.edu/animalscifacpub

Part of the Animal Sciences Commons

Nunez-Dominguez, R.; Van Vleck, L. Dale; Boldman, K. G.; and Cundiff, Larry V., "Correlations for Genetic Expression for Growth of Calves of Hereford and Angus Dams Using a Multivariate Animal Model" (1993). Faculty Papers and Publications in Animal Science. 249.

https://digitalcommons.unl.edu/animalscifacpub/249

This Article is brought to you for free and open access by the Animal Science Department at DigitalCommons@University of Nebraska - Lincoln. It has been accepted for inclusion in Faculty Papers and Publications in Animal Science by an authorized administrator of DigitalCommons@University of Nebraska - Lincoln. 


\title{
Correlations for Genetic Expression for Growth of Calves of Hereford and Angus Dams Using a Multivariate Animal Model ${ }^{1,2}$
}

\author{
R. Núñez-Dominguez*, L. D. Van Vleck ${ }^{*,+}$, K. G. Boldman ${ }^{*,+}$, and L. V. Cundiff ${ }^{\dagger}$ \\ *Department of Animal Science, University of Nebraska, Lincoln 68583-0908 and \\ ${ }^{\dagger}$ Roman L. Hruska U.S. Meat Animal Research Center, ARS, USDA, Clay Center, NE 68933
}

\begin{abstract}
The purpose of this study was to estimate the correlation between the expression of genes from sires in purebred and crossbred progeny $\left(r_{\mathrm{PC}}\right)$ and in Hereford and Angus $\mathrm{F}_{1}$ calves $\left(\mathrm{r}_{\mathrm{HA}}\right)$. Performance traits were weights at birth, $200 \mathrm{~d}$, and 365 d. Progeny from Hereford, Polled Hereford, and Angus bulls mated to Hereford or Angus cows were

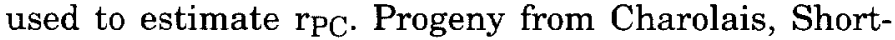
horn, Simmental, Limousin, Maine-Anjou, Chianina, Gelbvieh, Tarentaise, and Salers bulls mated to Hereford or Angus cows were used to estimate $\mathbf{r}_{\mathrm{HA}}$. Performances in purebreds ( $P$ ) and crosses (C) or in Hereford (H) and Angus (A) $\mathrm{F}_{1}$ calves were treated as separate traits. A multivariate animal model with birth year-cow age-sex subclasses, random correlated direct and maternal additive genetic effects, and maternal permanent environmental effects was used. Separate analyses were done by breed of sire. A derivative-free algorithm was used to obtain REML

estimates of (co)variance components. Weighted averages across breeds of estimates of heritability for P, C, $\mathrm{H}$, and $\mathrm{A}$ were, respectively, .61, .51, .47, and .40 for birth weight, $.41, .46, .37$, and .34 for weaning weight, and $.50, .49, .42$, and .46 for yearling weight. Estimates of $\mathrm{r}_{\mathrm{PC}}$ ranged from .88 to $.97, .55$ to .94 , and .68 to .86 for weights at birth, $200 \mathrm{~d}$, and $365 \mathrm{~d}$, respectively. Estimates of $r_{\mathrm{HA}}$ ranged from .43 to .99 , .56 to .95 , and .50 to .98 for weights at birth, $200 \mathrm{~d}$, and $365 \mathrm{~d}$, respectively. Weighted averages of estimates of $\mathrm{r}_{\mathrm{PC}}$ and $\mathrm{r}_{\mathrm{HA}}$ across sire breeds were, respectively, .93 and .85 for birth weight, .77 and .73 for weaning weight, and .76 and .86 for yearling weight. These results indicate that ranking of sires producing purebreds or crosses, or crossbred calves from different breeds of dams, is approximately the same for birth and yearling weights, but some reranking might occur for weaning weight.
\end{abstract}

Key Words: Genetic Correlation, Beef Cattle, Growth

J. Anim. Sci. 1993. 71:2330-2340

\section{Introduction}

Several reports have shown that selection based on EPD of sires for growth traits has resulted in significant genetic progress in the beef cattle industry (e.g., AAA, 1991; APHA, 1991). Sizable breed differences and heterosis effects for economically important traits have been observed (Long, 1980; Cundiff et al., 1986; Wyatt and Franke, 1986). These findings stimulated studies to use both within- and betweenbreed genetic variation (Kinghorn, 1982; Elzo and

\footnotetext{
${ }^{1}$ Published as paper no. 10186, Journal Ser., Nebraska Agric. Res. Div., Univ. of Nebraska, Lincoln.

${ }^{2}$ The senior author wishes to acknowledge research support of the Dept. of Anim. Sci. at the Univ. of Nebraska and partial financial support of Cosejo Nacional de Ciencia y Technologia (CONACYT), Mexico. His current address is: Depto. de Zootecnia, Universidad Autonoma Chapingo, Chapingo, Mexico 56230.

Received November 19, 1992.

Accepted April 15, 1993.
}

Famula, 1985; Swan and Kinghorn, 1992). Notter (1989) discussed the possibility of calculating acrossbreed EPD in beef cattle. One piece of information that is needed is to determine the importance of sire $x$ breed of dam interaction. If this interaction is important, then the use of models to predict genetic values of sires under a particular maternal environment may be needed (Elzo and Famula, 1985; Swan and Kinghorn, 1992).

Sire $x$ breed of dam interactions may be due to effects of scale and(or) reranking of breeding values of sires when mated to different breeds of dams. Falconer (1952) pointed out that the importance of genotype $\times$ environment interaction can be estimated with a genetic correlation (i.e., expression of a trait in two environments can be regarded as different traits that are genetically correlated). Thus, a genetic correlation smaller than unity indicates genotype $x$ environment interaction. Multiple-trait procedures to estimate genetic correlations between traits measured on different animals can be used to quantify the 
degree of reranking of sires' breeding values when mated to different dam breeds, and simultaneously to adjust for effects of scale.

The purpose of this study was to assess the importance of reranking of sires when mated to produce purebred or crossbred calves, as well as to produce $\mathrm{F}_{1}$ calves from Hereford or Angus dams.

\section{Materials and Methods}

Data came from a topcross experiment designed to characterize germplasm from different sire breeds representing diverse biological types when mated to Hereford and Angus cows at the Meat Animal Research Center (MARC) in Clay Center, NE. Although more than 26 sire breeds have been evaluated at MARC, only breeds with current national cattle genetic evaluations were included in this study. Sires of the Hereford, Angus, Polled Hereford, Simmental, Limousin, Charolais, Maine-Anjou, Chianina, Tarentaise, Shorthorn, Gelbvieh, and Salers breeds were mated to Hereford and Angus cows to produce the first generation of the Germplasm Evaluation Program (GPE). Figure 1 shows when the sire breeds were used at MARC. Some reference sires of the Hereford, Angus, and Polled Hereford breeds were used in all time periods (cycles) to provide ties among the data. New samples of Hereford, Angus, Polled Hereford, and Charolais bulls born since 1982 were used in cycle IV of the GPE program. Performance traits studied were birth weight, 200-d weight (weaning weight), and 365-d weight (yearling weight).

Calf performances in each maternal environment (breed of dam) were treated as separate traits. Sire breeds were divided into two groups so that two types of correlations were estimated from within breed of sire analyses. In the first group, Angus, Hereford, and Polled Hereford sire breeds produced purebred and crossbred calves, and so the first type of correlation estimated was between the expression of genes from the sires in purebred or crossbred calves ( $\mathbf{r}_{\mathbf{P C}}$ ). Polled Hereford $x$ Hereford crosses were considered purebreds. The second group included all other sire breeds producing $F_{1}$ cross calves from Hereford or Angus dams. Thus, the second type of correlation was between the expression of genes of the sires in crossbred calves out of Hereford or Angus cows ( $\mathbf{r}_{\mathbf{H A}}$ ).

Table 1 presents the number of sires, dams, and purebred and crossbred progeny for birth weight, weaning weight, and yearling weight. On average across sire breeds, 13 cows were mated per sire and $15 \%$ of the cows had more than one calf. Table 2 presents the number of sires, dams, and crossbred progeny from Hereford and Angus cows for birth weight, weaning weight, and yearling weight. Variation in number of animals existed across sire breeds. Charolais had the largest number of sires (65) and

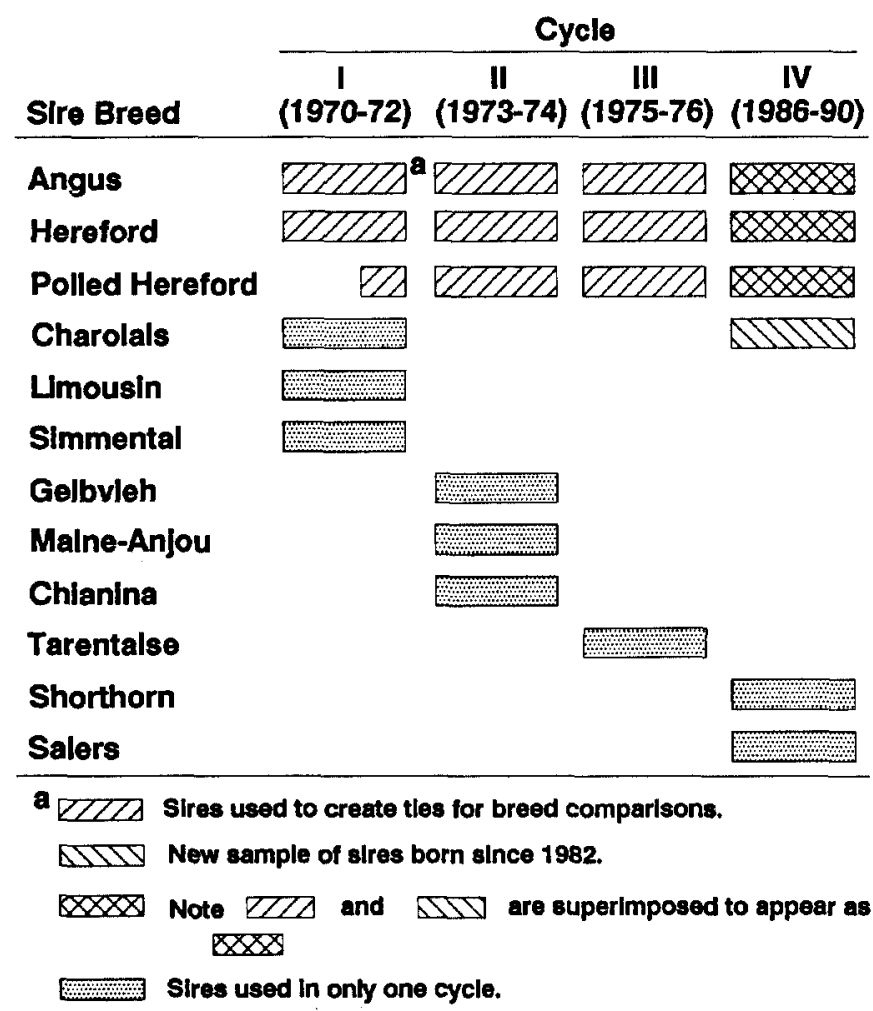

Figure 1. Periods of time when progeny from Hereford or Angus cows were produced out of several sire breeds.

Tarentaise the smallest (7). The number of progeny was largest for Charolais and smallest for Shorthorn. Averaged across sire breeds, 11 cows were mated per sire and $6 \%$ of the cows had more than one calf.

Management of these animals has been reported by Smith et al. (1976a,b), Laster et al. (1976, 1979), Gregory et al. $(1978,1979 a, b)$, and Cundiff et al. (1981, 1984). In brief, calves were born in the spring, castrated within $24 \mathrm{~h}$, and weaned at approximately $200 \mathrm{~d}$ of age, except that calves born in 1974 were weaned at $167 \mathrm{~d}$ of age because of drought conditions. After weaning, heifers were managed to calve first at $2 \mathrm{yr}$ of age and were fed a diet of approximately $50 \%$ corn silage and $50 \%$ alfalfa or grass haylage, plus protein and mineral supplement. Steers received a high-energy-density diet for approximately $196 \mathrm{~d}$, after a preconditioning period of 25 to $58 \mathrm{~d}$. Averaged across years and feeding periods, the diets contained (DM basis) approximately $12.8 \% \mathrm{CP}, 9.2 \%$ digestible protein, and $2.8 \mathrm{Mcal}$ of $\mathrm{ME} / \mathrm{kg}$.

\section{The Model}

The percentage of cows with more than one calf ranged from 2 to $18 \%$ across the different sire breeds. The first attempt to analyze these data fit a model with only direct genetic random effects, besides fixed effects. However, under this model estimates of 
Table 1. Number of sires of each sire breed mated to Hereford (HH) and Angus (AA) dams and numbers of purebred (PB) and crossbred (XX) calves with weights at birth (BWT), 200 days (WWT), and 365 days (YWT)

\begin{tabular}{|c|c|c|c|c|c|c|c|c|c|c|c|c|c|c|c|}
\hline \multirow[b]{3}{*}{ Breed of sire } & & & & \multicolumn{6}{|c|}{ No. of dams } & \multicolumn{6}{|c|}{ No. of progeny } \\
\hline & \multicolumn{3}{|c|}{ No. of sires } & \multicolumn{3}{|c|}{$\mathrm{HH}$} & \multicolumn{3}{|c|}{$\mathrm{AA}$} & \multicolumn{3}{|c|}{ PB } & \multicolumn{3}{|c|}{$\mathrm{xx}$} \\
\hline & BWT & WWT & YWT & BWT & WWT & YWT & BWT & WWT & YWT & BWT & WWT & YWT & BWT & WWT & YWT \\
\hline Angus & 81 & 81 & 81 & 512 & 491 & 465 & 430 & 402 & 392 & 494 & 461 & 446 & 626 & 595 & 551 \\
\hline Hereford & 55 & 54 & 53 & 306 & 284 & 276 & 474 & 456 & 418 & 329 & 302 & 289 & 571 & 540 & 484 \\
\hline Polled Hereford & 22 & 22 & 22 & 99 & 98 & 97 & 201 & 195 & 183 & 103 & 102 & 100 & 210 & 203 & 186 \\
\hline
\end{tabular}

additive genetic variances seemed to be biased upward because of covariance among records from the same dam, as discussed by James (1991) for the case of repeated records on the same animal. A second analysis fit both direct genetic and maternal permanent environment effects. Because traits such as birth weight, weaning weight, and even yearling weight of the calf are known to be influenced by the maternal environment, which is due in part to the genetic make up of the cow, a complete model should include, in addition to the previous effects, the genetic maternal effect plus the covariance between direct and maternal genetic effects.

A procedure outlined by James (1991) was extended to attempt to quantify the amount of bias in the estimate of the genetic variance for direct effects when fitting a model with only direct genetic and permanent environmental effects, assuming that the correct model also includes maternal genetic effects (see Appendix). Expectations of variance components based on MINQUE estimators were obtained. After using different combinations of variances due to direct genetic and permanent environmental effects relative to the phenotypic variance as starting values, this procedure suggested for these data that the genetic variance for direct effects would be biased upward by approximately $18 \%$ because of the variance of mater- nal genetic effects and by approximately $15 \%$ because of positive covariance between direct and maternal genetic effects. Hence, if the covariance between direct and maternal effects was negative but the same size as the variance for maternal effects, the bias would be nil.

A model including fixed environmental effects plus correlated direct and maternal additive genetic effects and maternal permanent environmental effects was assumed to be appropriate for these data. Because each performance trait was measured on calves of different dam breeds, except for direct and maternal genetic effects, all random effects were assumed to be uncorrelated. The model for traits (e.g., birth weight) expressed in Hereford or Angus maternal environments, $\mathbf{h}$ or $\mathbf{a}$, respectively, can be represented as follows:

$$
\begin{aligned}
& \mathbf{y}_{\mathrm{h}}=\mathbf{X}_{\mathrm{h}} \mathbf{b}_{\mathrm{h}}+\mathbf{Z}_{\mathrm{h}} \mathbf{g}_{\mathrm{h}}+\mathbf{M}_{\mathrm{h}} \mathbf{m}_{\mathrm{h}}+\mathbf{w}_{\mathrm{h}} \mathbf{p}_{\mathrm{h}}+\mathbf{e}_{\mathrm{h}} \\
& \mathbf{y}_{\mathrm{a}}=\mathbf{X}_{\mathrm{a}} \mathbf{b}_{\mathrm{a}}+\mathbf{Z}_{\mathrm{a}} \mathbf{g}_{\mathrm{a}}+\mathbf{M}_{\mathrm{a}} \mathbf{m}_{\mathrm{a}}+\mathbf{W}_{\mathrm{a}} \mathbf{p}_{\mathrm{a}}+\mathbf{e}_{\mathrm{a}}
\end{aligned}
$$

where $\mathbf{y}$ is the vector of observations, $\mathbf{b}$ is the vector of fixed effects (birth year-cow age-sex subclasses), $\mathbf{X}$ is the matrix that associates $\mathbf{b}$ with $\mathbf{y}, \mathbf{g}$ is the vector of breeding values for direct genetic effects, $\mathbf{Z}$ is the matrix that associates $\mathbf{g}$ with $\mathbf{y}, \mathbf{m}$ is the vector of breeding values for maternal genetic effects, $\mathbf{M}$ is the

Table 2. Number of sires of each sire breed mated to Hereford (HH) and Angus (AA) dams and numbers of Hereford (XH) and Angus (XA) crossbred calves with weights at birth (BWT), 200 days (WWT),

\begin{tabular}{|c|c|c|c|c|c|c|c|c|c|c|c|c|c|c|c|}
\hline \multirow[b]{3}{*}{ Breed of sire } & & & & \multicolumn{6}{|c|}{ No. of dams } & \multicolumn{6}{|c|}{ No. of progeny } \\
\hline & \multicolumn{3}{|c|}{ No. of sires } & \multicolumn{3}{|c|}{$\mathrm{HH}$} & \multicolumn{3}{|c|}{$\mathrm{AA}$} & \multicolumn{3}{|c|}{$\mathrm{XH}$} & \multicolumn{3}{|c|}{$\mathrm{XA}$} \\
\hline & BWT & WWT & YWT & BWT & WWT & YWT & BWT & WWT & YWT & BWT & WWT & YWT & BWT & WWT & YWT \\
\hline Charolais & 65 & 64 & 63 & 270 & 240 & 232 & 290 & 257 & 220 & 293 & 257 & 248 & 314 & 276 & 235 \\
\hline Shorthorn & 26 & 26 & 26 & 81 & 75 & 75 & 90 & 87 & 85 & 83 & 77 & 77 & 99 & 94 & 92 \\
\hline Simmental & 28 & 27 & 27 & 192 & 167 & 160 & 197 & 181 & 149 & 208 & 180 & 172 & 214 & 197 & 160 \\
\hline Limousin & 20 & 20 & 20 & 193 & 166 & 161 & 175 & 164 & 158 & 206 & 176 & 170 & 182 & 171 & 165 \\
\hline Maine-Anjou & 18 & 18 & 18 & 96 & 84 & 82 & 112 & 104 & 104 & 100 & 88 & 86 & 118 & 109 & 109 \\
\hline Chianina & 20 & 20 & 20 & 112 & 100 & 100 & 119 & 110 & 110 & 116 & 104 & 104 & 122 & 112 & 112 \\
\hline Gelbvieh & 24 & 24 & 24 & 164 & 150 & 148 & 177 & 166 & 164 & 175 & 160 & 158 & 187 & 173 & 171 \\
\hline Tarentaise & 7 & 7 & 7 & 66 & 62 & 61 & 125 & 123 & 119 & 68 & 64 & 63 & 131 & 127 & 123 \\
\hline Salers & 27 & 27 & 27 & 76 & 72 & 71 & 100 & 94 & 92 & 80 & 75 & 74 & 108 & 101 & 99 \\
\hline
\end{tabular}
and 365 days (YWT) 
matrix that associates $\mathbf{m}$ with $\mathbf{y , ~} \mathbf{p}$ is the vector of permanent environmental plus nonadditive genetic effects contributed by dams to their progeny, $W$ is the matrix that associates $\mathbf{p}$ with $\mathbf{y}$, and $\mathbf{e}$ is the vector of residual effects peculiar to observations that are not explained by other parts of the model. Birth date was included in $\mathbf{b}$ as a covariate for birth weight.

For both traits combined into single vectors and matrices, the multiple-trait animal model can be represented as follows:

$\left[\begin{array}{l}\mathbf{y}_{\mathrm{h}} \\ \mathbf{y}_{\mathrm{a}}\end{array}\right]=\left[\begin{array}{cc}\mathbf{x}_{\mathrm{h}} & \mathbf{0} \\ \mathbf{0} & \mathbf{x}_{\mathrm{a}}\end{array}\right]\left[\begin{array}{l}\mathbf{b}_{\mathrm{h}} \\ \mathbf{b}_{\mathrm{a}}\end{array}\right]+\left[\begin{array}{cc}\mathbf{z}_{\mathrm{h}} & \mathbf{0} \\ \mathbf{0} & \mathbf{z}_{\mathrm{a}}\end{array}\right]\left[\begin{array}{l}\mathbf{g}_{\mathrm{h}} \\ \mathbf{g}_{\mathrm{a}}\end{array}\right]$
$+\left[\begin{array}{cc}\mathbf{M}_{\mathrm{h}} & \mathbf{0} \\ \mathbf{0} & \mathbf{M}_{\mathrm{a}}\end{array}\right]\left[\begin{array}{l}\mathbf{m}_{\mathrm{h}} \\ \mathbf{m}_{\mathrm{a}}\end{array}\right]+\left[\begin{array}{cc}\mathbf{w}_{\mathrm{h}} \mathbf{0} \\ \mathbf{0} & \mathbf{w}_{\mathrm{a}}\end{array}\right]\left[\begin{array}{l}\mathbf{p}_{\mathrm{h}} \\ \mathbf{p}_{\mathrm{a}}\end{array}\right]+\left[\begin{array}{l}\mathbf{e}_{\mathrm{h}} \\ \mathbf{e}_{\mathrm{a}}\end{array}\right]$

with

$$
\mathbf{E}\left[\begin{array}{l}
\mathbf{y}_{\mathrm{h}} \\
\mathbf{y}_{\mathrm{a}}
\end{array}\right]=\left[\begin{array}{cc}
\mathbf{x}_{\mathrm{h}} & \mathbf{0} \\
\mathbf{0} & \mathbf{x}_{\mathrm{a}}
\end{array}\right]\left[\begin{array}{l}
\mathbf{b}_{\mathrm{h}} \\
\mathbf{b}_{\mathrm{a}}
\end{array}\right]
$$

and

$\operatorname{Var}\left[\begin{array}{c}\mathbf{g}_{\mathrm{h}} \\ \mathbf{g}_{\mathrm{a}} \\ \mathbf{m}_{\mathrm{h}} \\ \mathbf{m}_{\mathrm{a}}\end{array}\right]=\left[\begin{array}{cccc}\sigma_{\mathrm{g}_{\mathrm{h}}}^{2} \mathbf{A} & \sigma_{\mathrm{g}_{\mathrm{ha}}} \mathbf{A} & \sigma_{\mathrm{gm}_{\mathrm{h}}} \mathbf{A} & \mathbf{0} \\ \sigma_{\mathrm{g}_{\mathrm{ha}}} \mathbf{A} & \sigma_{\mathrm{g}_{\mathrm{a}}}^{2} \mathbf{A} & \mathbf{0} & \sigma_{\mathrm{gm}_{\mathrm{a}}} \mathbf{A} \\ \sigma_{\mathrm{gm}_{\mathrm{h}}} \mathbf{A} & \mathbf{0} & \sigma_{\mathrm{m}_{\mathrm{h}}}^{2} \mathbf{A} & \mathbf{0} \\ \mathbf{0} & \sigma_{\mathrm{gm}_{\mathrm{a}}} \mathbf{A} & \mathbf{0} & \sigma_{\mathrm{m}_{\mathrm{a}}}^{2} \mathbf{A}\end{array}\right]$,

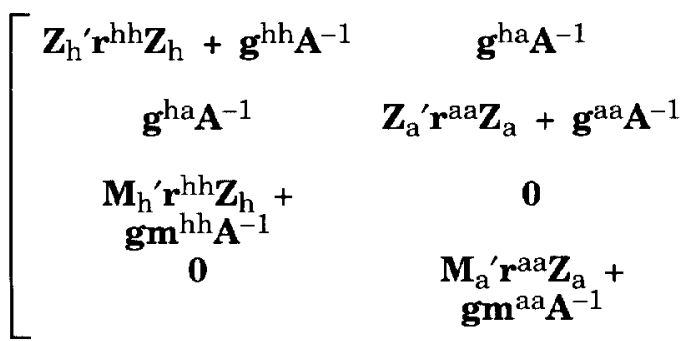

Note that the covariance for direct genetic effects between traits will be estimated based only on the relationships between calves of Hereford and Angus cows.

\section{Estimation of (Co/variance Components}

Variance components were estimated by REML procedures. Maximum likelihood estimation consists of obtaining estimates of the parameters (i.e., variance components) that maximize the likelihood function $(\lambda)$. Maximizing $\lambda$ is the same as maximizing the $\log \lambda$, or minimizing $-2 \log \lambda$, which can be written as follows:

$$
\begin{aligned}
& \operatorname{Var}\left[\begin{array}{l}
\mathbf{p}_{\mathrm{h}} \\
\mathbf{p}_{\mathrm{a}}
\end{array}\right]=\left[\begin{array}{cc}
\sigma_{\mathrm{p}_{\mathrm{h}}}^{2} \mathbf{I} & \mathbf{0} \\
\mathbf{0} & \sigma_{\mathrm{p}_{\mathrm{a}}}^{2} \mathbf{I}
\end{array}\right], \\
& \operatorname{Var}\left[\begin{array}{c}
\mathbf{e}_{\mathrm{h}} \\
\mathbf{e}_{\mathrm{a}}
\end{array}\right]=\left[\begin{array}{cc}
\sigma_{\mathrm{e}_{\mathrm{h}}}^{2} \mathbf{I} & \mathbf{0} \\
\mathbf{0} & \sigma_{\mathrm{e}_{\mathrm{a}}}^{2} \mathbf{I}
\end{array}\right]
\end{aligned}
$$

where $\mathbf{A}$ is the numerator relationship matrix and I are identity matrices of appropriate order, and the $\mathbf{g}$, $\mathbf{p}$, and $\mathbf{e}$ vectors are uncorrelated. The variancecovariance matrix for genetic effects is $\mathbf{G}=\mathbf{G}_{\mathbf{0}} * \mathbf{A}$, with $\mathbf{G}^{-1}=\mathbf{G}_{0}^{-1} * \mathbf{A}^{-1}$, and the variance-covariance matrix for residual effects is $\mathbf{R}=\mathbf{R}_{0} * \mathbf{I}$, with $\mathbf{R}^{-1}=$ $\mathbf{R}_{0}^{-1 *} \mathbf{I}$, where $\mathbf{G}_{0}^{-1}$ and $\mathbf{R}_{0}^{-1}$ are symbolized as follows:

$$
\mathbf{G}_{0}^{-1}=\left[\begin{array}{cccc}
\mathbf{g}^{\mathrm{hh}} & \mathbf{g}^{\mathrm{ha}} & \mathbf{g m}^{\mathbf{h h}} & \mathbf{0} \\
\mathbf{g}^{\mathrm{ha}} & \mathbf{g}^{\mathrm{aa}} & \mathbf{0} & \mathbf{g m}^{\text {aa }} \\
\mathbf{g m}^{\mathrm{hh}} & \mathbf{0} & \mathbf{m}^{\mathrm{hh}} & \mathbf{0} \\
\mathbf{0} & \mathbf{g m}^{\text {aa }} & \mathbf{0} & \mathbf{m}^{\text {aa }}
\end{array}\right]
$$

and

$$
\mathbf{R}_{0}^{-1}=\left[\begin{array}{cc}
\mathbf{r}^{\mathrm{hh}} & \mathbf{0} \\
\mathbf{0} & \mathbf{r}^{\mathrm{aa}}
\end{array}\right] .
$$

The mixed-model equations can be represented as $\mathbf{C} \hat{\mathbf{s}}=\mathbf{r}$, where $\mathbf{C}$ is the coefficient (left-hand side) matrix, $\hat{\mathbf{s}}$ is the solution vector, and $\mathbf{r}$ is the vector of right-hand sides. The diagonal block of $\mathbf{C}$ associated with direct and maternal genetic effects can be written as follows:

$$
\begin{gathered}
\mathbf{Z}_{\mathrm{h}^{\prime} \mathbf{r}^{\mathrm{hh}} \mathbf{M}_{\mathrm{h}}}+ \\
\mathbf{g m}_{\mathbf{0} h}^{\mathbf{A}^{-1}} \\
\mathbf{0} \\
\mathbf{M}_{\mathbf{h}} \mathbf{r}^{\mathrm{hh}} \mathbf{M}_{\mathrm{h}} \\
\mathbf{m}_{\mathbf{0}}^{\mathrm{hh}} \mathbf{A}^{-1} \\
\mathbf{0}
\end{gathered}
$$

$$
\begin{aligned}
\text { constant } & +\log |\mathbf{G}|+\log |\mathbf{S}|+\log |\mathbf{R}| \\
& +\log \left|\mathbf{C}^{\circ}\right|+\mathbf{y}^{\prime} \mathbf{P y}
\end{aligned}
$$

where $\mathbf{S}$ is the variance-covariance matrix for maternal permanent environmental effects, $\mathbf{C}^{\circ}$ is the full rank coefficient matrix, and $\mathbf{y}^{\prime} \mathbf{P y}$ is the generalized residual sum of squares.

Meyer (1991) presented ways to evaluate the likelihood function for the multiple-trait case. Meyer used Gaussian elimination procedures to evaluate simultaneously $\log \mid \mathbf{C l}$ and $\mathbf{y}^{\prime} \mathbf{P y}$, which are the most expensive in terms of computer time. Boldman and 
Van Vleck (1991) described the use of a sparse matrix software package, SPARSPAK (George et al., 1980), to evaluate more efficiently these two components. Thus, the evaluation of the likelihood function was done as follows:

$$
\begin{aligned}
& \log |\mathbf{G}|=N A\left[\sum_{i=1}^{n g} \text { eigen }\left(\mathbf{G}_{0}\right)\right]+n g \cdot \log |\mathbf{A}|, \\
& \log |\mathbf{S}|=\sum_{i=1}^{n t} N C_{i} \cdot \log \sigma_{\mathrm{p}_{i}}^{2}, \\
& \log |\mathbf{R}|=\sum_{i=1}^{n t} N R_{i} \cdot \log \sigma_{\mathrm{e}_{i}}^{2}
\end{aligned}
$$

where NA is the number of animals in the relationship matrix, $\mathbf{n g}$ is the order of $\mathbf{G}_{\mathbf{o}}$, $\mathbf{n t}$ is the number of traits, $\mathbf{N C}_{\mathbf{i}}$ is the number of dams for trait $\mathbf{i}$, and $\mathbf{N R}_{\mathbf{i}}$ is the number of records of trait $i$.

Computation of $\log \left|\mathbf{C}^{\circ}\right|$ and $\mathbf{y}^{\prime} \mathbf{P y}$ was based on a Cholesky factorization of the coefficient matrix as follows (Boldman and Van Vleck, 1991). If $\mathbf{C}^{\circ}=\mathbf{L} \mathbf{L}^{\prime}$, where $\mathbf{L}$ is the Cholesky factor, a lower triangular matrix, then

$$
\log \left|\mathbf{C}^{\circ}\right|=\sum_{\mathrm{i}=1}^{\mathrm{nc}} \log \left(\mathbf{l}_{\mathrm{ii}}^{2}\right)
$$

and

$$
\mathbf{y}^{\prime} \mathbf{P y}=\mathbf{y}^{\prime} \mathbf{R}^{-1} \mathbf{y}-\hat{\mathbf{s}}^{\prime} \mathbf{r}
$$

where nc is the rank of $\mathbf{C}$, and $\hat{\mathbf{s}}$ is computed by successively solving two triangular systems by forward and backward substitution.
Optimization of the likelihood function was done through direct search, that is, without the use of derivatives, using the downhill simplex algorithm of Nelder and Mead (1965). Iterations were stopped when the variance of function values $(-2 \log \lambda)$ of the simplex was less than $1 \times 10^{-9}$.

This multiple-trait DFREML program was developed by K. Boldman and D. Van Vleck at the University of Nebraska. This program allows data with missing observations and different models for the various traits.

The same model was used on both types of data sets: 1) purebred and crossbred and 2) Hereford and Angus $F_{1}$ crosses.

\section{Results and Discussion}

\section{Genetic Parameters for Purebreds and Crosses}

Estimates of direct $\left(\mathbf{h}^{2}\right)$ and maternal $\left(\mathbf{m}^{2}\right)$ heritabilities, of correlations between direct and maternal ( $\left.\mathbf{r}_{\mathbf{G M}}\right)$ genetic effects, and of ratios of variances of permanent environmental ( $\mathbf{c}^{2}$ ) effects to the phenotypic variance for different performance traits of purebred and crossbred calves are shown in Table 3.

Meyer (1989) evaluated ways to approximate standard errors of variance components for single-trait models with increasing number of random effects. The approximation was somewhat satisfactory only for the cases of models with direct genetic or direct genetic plus permanent environmental effects. With multipletrait models, the problem of approximation is even

\begin{tabular}{|c|c|c|c|c|c|c|c|c|c|c|c|}
\hline Breed of sire & $\mathbf{h}_{\mathrm{P}}^{2}$ & $\mathrm{~h}_{\mathrm{C}}^{2}$ & $\mathbf{r}_{\mathrm{PC}}$ & $\mathrm{m}_{\mathrm{P}}^{2}$ & $\mathrm{~m}_{\mathrm{C}}^{2}$ & $\mathbf{r}_{\mathrm{GM}}(\mathrm{P})$ & $r_{\mathrm{GM}}(\mathrm{C})$ & $c_{\mathrm{P}}^{2}$ & $c_{\mathrm{C}}^{2}$ & $\sigma_{\mathrm{T}}^{2}(\mathrm{P})$ & $\sigma_{T}^{2}(\mathbf{C})$ \\
\hline Angus & .62 & .63 & .92 & .01 & .12 & $\begin{array}{c}\text { Birth wt } \\
-.40\end{array}$ & .00 & .23 & .03 & 17.4 & 16.0 \\
\hline Hereford & .60 & .41 & .97 & 17 & .17 & .22 & -.09 & .00 & .00 & 21.7 & 19.1 \\
\hline Polled Hereford & .58 & .42 & .88 & .03 & .42 & .46 & .12 & .33 & .09 & 24.8 & 16.8 \\
\hline Average $^{\mathrm{a}}$ & .61 & .51 & .93 & .06 & .18 & -.08 & -.01 & .15 & .02 & 19.7 & 17.5 \\
\hline Angus & .50 & .51 & .94 & .21 & .29 & .25 & .22 & .11 & .00 & 463.4 & 610.8 \\
\hline Hereford & .25 & 41 & .55 & .26 & .44 & .63 & -.38 & .00 & .05 & 532.6 & 472.9 \\
\hline Polled Hereford & .45 & .48 & .77 & .22 & .02 & .18 & .55 & .24 & .19 & 667.2 & 463.3 \\
\hline Average $^{a}$ & .41 & .46 & .77 & .22 & .30 & .38 & .03 & .08 & .04 & 511.1 & 531.5 \\
\hline Angus & .56 & .42 & .68 & .14 & .20 & .38 & .59 & .03 & .01 & $1,185.8$ & $1,262.1$ \\
\hline Hereford & .47 & .59 & .86 & .17 & .19 & .12 & .50 & .26 & .00 & $1,130.1$ & $1,237.6$ \\
\hline Polled Hereford & .36 & .49 & .80 & .26 & .16 & .44 & -.44 & .02 & .18 & 797.9 & 726.6 \\
\hline Average $^{\mathrm{a}}$ & .50 & .49 & .76 & .16 & .18 & .30 & .40 & .10 & .03 & $1,279.2$ & $1,136.2$ \\
\hline
\end{tabular}

Table 3. Estimates of the variances relative to the phenotypic variance $\left(\sigma_{\mathrm{T}}^{2}\right)$ for direct $\left(\mathrm{h}^{2}\right)$ and maternal $\left(\mathrm{m}^{2}\right)$ genetic effects and permanent environmental $\left\langle c^{2}\right\rangle$ effects and of correlations between direct and maternal $\left\langle r_{\mathrm{GM}}\right\rangle$ genetic effects and of correlations $\left\langle\mathrm{r}_{\mathrm{PC}}\right\rangle$ between the genetic expression of genes from the sires in purebred $(\mathrm{P})$ and crossbred (C) calves with weights at birth, 200 days, and 365 days by breed of sire

\footnotetext{
aweighted by the number of records in each sire-dam combination.
} 
worse. Consequently, estimates of standard errors for estimates in Table 3 were not computed.

No obvious differences for $h^{2}$ between purebreds and crosses were observed across the different performance traits. Average estimates of $h^{2}$ for purebreds and crosses across sire breeds were, respectively, .61 and .51 for birth weight, .41 and .46 for 200 -d weight, and .50 and .49 for 365 -d weight. These estimates are somewhat larger than most previous estimates in the literature (e.g., Koger et al., 1975; Woldehawariat et al., 1977; Meyer et al., 1991). Woldehawariat et al. (1977) reported average heritabilities of $.45, .24$, and .44 for birth, weaning, and yearling weights, respectively. Larger estimates of $h^{2}$, for Hereford and Angus calves, respectively, were reported for birth weight (.42 and .58$)$ and weaning weight (.63 and .66) by Brown et al. (1990).

Estimates of $\mathrm{m}^{2}, \mathrm{c}^{2}$, and $\mathrm{r}_{\mathrm{GM}}$ were quite variable across breeds of sires. Although the amount of information available to obtain estimates of maternal and permanent environmental effects was limited, those effects were included in the model to improve estimates of variances and covariances for direct genetic effects. Ignoring maternal effects can substantially inflate estimates of direct heritability (Mrode and Thompson, 1990; Meyer et al., 1991).

Generally, estimates of $\mathrm{m}^{2}$ were smaller than $\mathrm{h}^{2}$ for both purebreds and crosses and for each performance trait. Average estimates of $\mathrm{m}^{2}$ for purebreds and crosses by sire breed were, respectively, .06 and .18 for birth weight, .22 and .30 for 200 -d weight, and .16 and .18 for 365-d weight. Larger estimates of heritability for direct than for maternal effects in Hereford and Angus calves have been reported for birth weight by Brown et al. (1990) and Kriese et al. (1991) and also for yearling weight by Meyer et al. (1991).

Estimates of $r_{\mathrm{GM}}$ for birth weight of purebred and crossbred calves ranged from -.40 to .46 . Averaged across sire breeds, $r_{\mathrm{GM}}$ were -.08 and -.01 for purebreds and crosses, respectively. For weight at 200 and $365 \mathrm{~d}$ most estimates of $\mathrm{r}_{\mathrm{GM}}$ were positive. Averaged across sire breeds, estimates of $r_{\mathrm{GM}}$ for purebreds and crosses were, respectively, .38 and .03 for 200-d weight and .30 and .40 for 365-d weight. Negative estimates of $r_{G M}$ for growth traits commonly have been reported (Koch, 1972; Brown et al., 1990; Kriese et al., 1991; Meyer et al., 1991), although some reports of positive correlations between direct and maternal genetic effects also exist (Koch, 1972; Meyer et al., 1991).

Estimates of $c^{2}$ were generally smaller than those for $\mathrm{m}^{2}$. Averaged across sire breeds, estimates of $\mathrm{c}^{2}$ for purebreds and crosses were, respectively, .15 and .02 for birth weight, .08 and .04 for 200-d weight, and .10 and .03 for $365-\mathrm{d}$ weight.

Correlations Between Purebreds and Crosses. Table 3 also shows estimates of correlations for genetic expression for growth traits in purebred and crossbred $\left(r_{\mathrm{PC}}\right)$ calves. All correlations were positive and larger than .54. Average (weighted by number of calves) estimates were $.93, .77$, and .76 for weights at birth and 200 and $365 \mathrm{~d}$, respectively. Correlations between purebreds and crosses usually have been estimated to predict the potential use of selection methods to improve performance of crossbred animals (i.e., reciprocal recurrent selection [Wei and van der Steen, 1991]). In general, if $\mathbf{r}_{P C}$ is large and positive, methods using purebred selection are more effective than using reciprocal recurrent selection.

The other use of $\mathrm{rPC}_{\mathrm{PC}}$ is an indicator of sire $x$ breed of dam interactions, that is, to quantify how well the EPD from purebred data of a bull predicts performance of crossbred calves. The results indicate that ranking of bulls for producing purebred calves is different from that for producing crossbred calves, because the correlations were $<1.0$. The question is, What value of $\mathbf{r P C}_{\mathrm{PC}}$ will be of biological and economic importance (i.e., such that effects of reranking of sire's

Table 4. Estimates of the variances relative to the phenotypic variance $\left(\sigma_{\mathrm{T}}^{2}\right)$ for direct $\left(\mathrm{h}^{2}\right)$ and maternal $\left(\mathrm{m}^{2}\right)$ genetic effects and permanent environmental $\left\langle\mathrm{c}^{2}\right\rangle$ effects and of correlations between direct and maternal $\left(\mathrm{r}_{\mathrm{GM}}\right)$ genetic effects and of correlations $\left(\mathrm{r}_{\mathrm{HA}}\right)$ between the expression of genes from the sires in Hereford (H) and Angus (A) crossbred calves with birth weight by breed of sire

\begin{tabular}{|c|c|c|c|c|c|c|c|c|c|c|c|}
\hline Breed of sire & $\mathrm{h}_{\mathrm{H}}^{2}$ & $\mathrm{~h}_{\mathrm{A}}^{2}$ & $\mathrm{r}_{\mathrm{HA}}$ & $\mathrm{m}_{\mathrm{H}}^{2}$ & $\mathrm{~m}_{\mathrm{A}}^{2}$ & $\mathbf{r}_{\mathrm{GM}^{(}}(\mathrm{H})$ & $r_{G M}(A)$ & $c_{\mathrm{H}}^{2}$ & $c_{\mathrm{A}}^{2}$ & $\sigma_{\mathrm{T}}^{2}(\mathrm{H})$ & $\sigma_{\mathrm{T}}^{2}(\mathrm{~A})$ \\
\hline Charolais & .51 & .44 & .93 & .36 & .11 & -.13 & .36 & .04 & .33 & 23.4 & 23.8 \\
\hline Shorthorn & .40 & .39 & .38 & .19 & .04 & .53 & .81 & .06 & .16 & 33.5 & 23.4 \\
\hline Simmental & .31 & .46 & .94 & .03 & .28 & -.08 & .32 & .03 & .03 & 21.9 & 19.5 \\
\hline Limousin & .54 & .44 & .83 & .32 & .29 & .34 & .44 & .00 & .02 & 14.9 & 16.7 \\
\hline Maine-Anjou & .65 & .41 & .43 & .06 & .02 & .78 & .73 & .13 & .00 & 22.8 & 31.7 \\
\hline Chianina & .54 & .45 & .99 & .09 & .36 & .06 & .09 & .07 & .05 & 27.3 & 31.4 \\
\hline Gelbvieh & .62 & .53 & .95 & .23 & .21 & .00 & -.31 & .12 & .07 & 24.2 & 23.8 \\
\hline Tarentaise & .36 & .16 & .86 & .34 & .03 & .20 & .47 & .21 & .04 & 17.7 & 16.6 \\
\hline Salers & .10 & .15 & .93 & .06 & .51 & -.01 & -.37 & .74 & .17 & 22.3 & 23.4 \\
\hline Average $^{a}$ & .47 & .40 & .85 & .20 & .19 & .12 & .27 & .10 & .11 & 22.5 & 22.9 \\
\hline
\end{tabular}

${ }^{a}$ Weighted by the number of records in each sire-dam combination. 
Table 5. Estimates of the variances relative to the phenotypic variance $\left(\sigma_{\mathrm{T}}^{2}\right)$ for direct $\left\langle\mathrm{h}^{2}\right)$ and maternal $\left(\mathrm{m}^{2}\right)$ genetic effects and permanent environmental $\left(\mathrm{c}^{2}\right)$ effects and of correlations between direct and maternal $\left(\mathrm{r}_{\mathrm{GM}}\right)$ genetic effects and of correlations $\left(\mathrm{r}_{\mathrm{HA}}\right)$ between the expression of genes from sires in Hereford $(\mathrm{H})$ and Angus (A) crossbred calves with 200-day weight by breed of sire

\begin{tabular}{|c|c|c|c|c|c|c|c|c|c|c|c|}
\hline Breed of sire & $\mathrm{h}_{\mathrm{H}}^{2}$ & $h_{\mathbf{A}}^{2}$ & $\mathbf{r}_{\mathrm{HA}}$ & $\mathrm{m}_{\mathrm{H}}^{2}$ & $\mathrm{~m}_{\mathrm{A}}^{2}$ & $\mathbf{r}_{\mathrm{GM}}(\mathrm{H})$ & $\mathrm{r}_{\mathrm{GM}}(\mathrm{A})$ & $c_{\mathrm{H}}^{2}$ & $c_{\mathrm{A}}^{2}$ & $\sigma_{\mathrm{T}}^{2}(\mathrm{H})$ & $\sigma_{\mathrm{T}}^{2}(\mathrm{~A})$ \\
\hline Charolais & .33 & .18 & .54 & .34 & .15 & .30 & .54 & .01 & .02 & 823.4 & 540.4 \\
\hline Shorthorn & .31 & .36 & .95 & .41 & .02 & .24 & -.07 & .09 & .01 & 657.5 & 595.3 \\
\hline Simmental & .45 & .55 & .72 & .14 & .28 & .46 & -.59 & .14 & .37 & 401.0 & 448.8 \\
\hline Limousin & .41 & .43 & .66 & .13 & .27 & .69 & .29 & .18 & .04 & 609.5 & 678.4 \\
\hline Maine-Anjou & .42 & .36 & .56 & .13 & .15 & .43 & .51 & .02 & .20 & 699.2 & 575.3 \\
\hline Chianina & .44 & .42 & .74 & .27 & .45 & .34 & .23 & .11 & .02 & 577.9 & 638.3 \\
\hline Gelbvieh & .24 & .21 & .92 & .03 & .00 & -.38 & -.03 & .48 & .22 & 714.6 & 447.2 \\
\hline Tarentaise & .43 & .48 & .82 & .20 & .22 & .41 & .43 & .12 & .01 & 710.9 & 573.8 \\
\hline Salers & .41 & .21 & .95 & .17 & .70 & .27 & .19 & .16 & .01 & 787.6 & 489.6 \\
\hline Average $^{a}$ & .37 & .34 & .73 & .19 & .22 & .30 & .17 & .14 & .11 & 662.4 & 546.6 \\
\hline
\end{tabular}

${ }^{\text {aW }}$ Weighted by the number of records in each sire-dam combination.

true breeding values should be considered in genetic evaluations)? Robertson (1959) addressed this question and suggested that correlations $<.8$ would be of biological importance. In this study estimates of $\mathrm{r}_{\mathrm{PC}}$ for weaning weight of Hereford (.55) sires and for yearling weight of Angus (.68) were relatively low. The average estimates of $\mathrm{r}_{\mathrm{PC}}$ for the performance traits, based on Robertson's previous criterion, suggest that important reranking might occur for weights at 200 and $365 \mathrm{~d}$ of purebred and crossbred Hereford and Angus calves.

Genetic Parameters for Hereford and Angus Crosses. Estimates of direct $\left(\mathrm{h}^{2}\right)$ and maternal $\left(\mathrm{m}^{2}\right)$ heritabilities, of correlations between direct and maternal $\left(r_{\mathrm{GM}}\right)$ genetic effects, and of ratios of variances of permanent environmental $\left(c^{2}\right)$ effects to the phenotypic variance for birth weight on Hereford and Angus crosses are shown in Table 4. Estimates for 200- and 365-d weights are shown in Tables 5 and 6. Large differences in $h^{2}$ were observed for birth and
365 - $d$ weights, but these estimates were less variable for weaning weight. For Hereford and Angus crosses, respectively, estimates of $\mathrm{h}^{2}$ ranged from .10 to .65 and from .15 to .53 for birth weight, from .24 to .45 and from .18 to .55 for weaning weight, and from .15 to .67 and from .17 to .75 for yearling weight. Averaged across sire breeds (weighted by the number of calves), estimates of $\mathrm{h}^{2}$ for Hereford and Angus crosses were, respectively, .47 and .40 for birth weight, .37 and .34 for weaning weight, and .42 and .46 for yearling weight. The average estimates of $h^{2}$ are within the range of values previously reported in the literature (e.g., Woldehawariat et al., 1977; Bertrand and Benyshek, 1987; Mrode and Thompson, 1990).

Averaged across sire breeds, estimates of $\mathrm{m}^{2}$ for Hereford and Angus crosses were, respectively, .20 and .19 for birth weight, .19 and .22 for 200 -d weight, and .15 and .15 for 365 -d weight. These estimates were generally smaller than estimates for direct heritability, which agrees with reports of

Table 6. Estimates of the variances relative to the phenotypic variance $\left\langle\sigma_{T}^{2}\right\rangle$ for direct $\left\langle h^{2}\right\}$ and maternal $\left(\mathrm{m}^{2}\right\rangle$ genetic effects and permanent environmental $\left(c^{2}\right)$ effects and of correlations between direct and maternal $\left(r_{\mathrm{GM}}\right)$ genetic effects and of correlations $\left(\mathrm{r}_{\mathrm{HA}}\right)$ between the expression of genes form the sires in Hereford (H) and Angus (A) crossbred calves with 365-day weight by breed of sire

\begin{tabular}{|c|c|c|c|c|c|c|c|c|c|c|c|}
\hline Breed of sire & $\mathrm{h}_{\mathrm{H}}^{2}$ & $\mathrm{~h}_{\mathrm{A}}^{2}$ & $\mathbf{r}_{\mathrm{HA}}$ & $\mathrm{m}_{\mathrm{H}}^{2}$ & $\mathrm{~m}_{\mathrm{A}}^{2}$ & $\mathrm{r}_{\mathrm{GM}}(\mathrm{H})$ & $r_{\mathrm{GM}}(\mathrm{A})$ & $c_{\mathrm{H}}^{2}$ & $c_{\mathrm{A}}^{2}$ & $\sigma_{\mathrm{T}}^{2}(\mathbf{H})$ & $\sigma_{\mathrm{T}}^{2}(\mathrm{~A})$ \\
\hline Charolais & .43 & .67 & .98 & .02 & .01 & .14 & .11 & .35 & .00 & $1,257.2$ & $1,197.3$ \\
\hline Shorthorn & .15 & .17 & .87 & .01 & .10 & .35 & -.37 & .60 & .08 & $1,454.8$ & $1,231.1$ \\
\hline Simmental & .67 & .46 & .87 & .13 & .08 & .49 & -.04 & .00 & .19 & 777.2 & $1,079.3$ \\
\hline Limousin & .38 & .30 & .90 & .13 & .21 & .15 & .41 & .45 & .00 & $1,278.4$ & 779.9 \\
\hline Maine-Anjou & .39 & .28 & .50 & .17 & .16 & .37 & .84 & .23 & .00 & 963.8 & 863.4 \\
\hline Chianina & .23 & .75 & .97 & .52 & .16 & .12 & .00 & .17 & .00 & 924.9 & 882.5 \\
\hline Gelbvieh & .51 & .65 & .92 & .23 & .46 & .34 & -.20 & .00 & .00 & $1,545.4$ & $1,117.9$ \\
\hline Tarentaise & .47 & .21 & .59 & .09 & .03 & .31 & .44 & .16 & .11 & 594.0 & 748.8 \\
\hline Salers & .17 & .38 & .77 & .23 & .21 & .62 & .17 & .16 & .20 & 623.5 & 798.7 \\
\hline Average $^{\mathrm{a}}$ & .42 & .46 & .86 & .15 & .15 & .29 & .14 & .23 & .05 & $1,176.7$ & 988.4 \\
\hline
\end{tabular}

aWeighted by the number of records in each sire-dam combination. 
Bertrand and Benyshek (1987) for Limousin and Brangus calves and Garrick et al. (1989) for Simmental-sired calves. Estimates of $r_{\mathrm{GM}}$ were generally positive and averaged across sire breeds for Hereford and Angus crosses were, respectively, .12 and .27 for birth weight, .30 and .17 for 200 -d weight, and .29 and .14 for 365-d weight. These results are different from most reports in the literature (Koch, 1972; Bertrand and Benyshek, 1987; Garrick et al., 1989), which have found negative correlations between direct and maternal genetic effects for growth traits.

Variance of permanent environmental effects for Hereford and Angus crosses, respectively, accounted on the average for 10 and $11 \%$ of the phenotypic variance for birth weight, 14 and $11 \%$ for 200-d weight, and 23 and 5\% for 365-d weight.

Correlations Between Hereford and Angus Crosses. Estimates of correlations ( $\mathrm{r}_{\mathrm{HA}}$ ) for the genetic expression for growth traits of first-cross calves from various sire breeds mated to Hereford or Angus dams are shown in Tables 4, 5, and 6 for weights at birth, $200 \mathrm{~d}$, and $365 \mathrm{~d}$, respectively. For birth weight all estimates of $\mathrm{r}_{\mathrm{HA}}$ were $>.80$, except for Shorthorn (.38) and Maine-Anjou (.43) sire breeds. For yearling weight most of the estimates of $\mathrm{r}_{\mathrm{HA}}$ were $>.80$, except for Maine-Anjou (.50), Tarentaise (.59), and Salers (.77) sire breeds. However, for weaning weight many estimates of $\mathrm{r}_{\mathrm{HA}}$ were $<.80$ and the average (weighted by the number of calves) across sire breeds was .73 . Thus, there is an indication that rankings of sires for weaning weight might change when those sires are used to produce crossbred calves from Hereford or Angus maternal environments.

General. Interest in estimates of correlation between purebred and crossbred progeny, or between crossbred progeny from different breeds of dam, results from interest in taking advantage of both within- and among-breed selection. National cattle evaluations in the beef industry are currently carried out on approximately 18 breeds and are based mainly on purebred data. Several studies have estimated the importance of sire $\times$ breed of mate interactions, either by looking at the significance of the interaction effect from the analysis of variance, or at estimates of correlations between estimated breeding values of sires producing progeny from different dam breeds. Results have been somewhat contradictory. Koger et al. (1975), working with Angus, Hereford, and Brahman cattle, reported that interactions of sire $x$ breed of dam were not significant, and genetic correlations between purebred and backcross progeny were .95 and 1.07 for birth and 205-d weights. Large correlations between purebred and half-sib Angus, Hereford, and Shorthorn calves were also observed by Dunn et al. (1970) for birth and weaning weights. However, other results have indicated important sire $x$ breed of dam interactions. Massey and Benyshek (1981) found interactions when Limousin sires were mated to Hereford and Angus cows to be significant. Correlations between responses in Hereford and Angus crosses were $.81, .78$, and .62 for weights at birth, $205 \mathrm{~d}$, and $365 \mathrm{~d}$. Also, Tilsch et al. (1989), working with Simmental and Charolais commercial calves, reported that correlations between breeding values of purebreds and crosses were low, ranging from -.01 to .46 .

All previous studies have assumed equal variances across breeds, which makes it difficult to distinguish how much of the interaction effect is due to changes in rank for a sire's progeny from one breed of dam to another and how much is due to changes in magnitude of sire differences (i.e., heterogeneity of variances). In the present study, variances and covariances were estimated for each breed group and, therefore, potential heterogeneity of variances was taken into account. Thus, estimates of correlations reported here should reflect the magnitude of association of true breeding values of the sires when mated to different breeds of dam. Although large sampling errors are associated with the correlation estimates, because they are based only on relationships between half-sib groups, these results indicate that reranking of sires might occur when these sires are used to produce purebreds and crosses, or crossbred calves from different breeds of dams, particularly for 200-d weight.

Currently, performance records for cattle genetic evaluations in the beef industry are obtained almost entirely in purebred herds. Considering the possible costs involved in obtaining and analyzing records from crossbred cattle, and given that correlations across maternal environments were large and positive, justification for changing genetic evaluation procedures would be difficult.

Procedures to consider sire $\times$ breed of dam interactions in cattle genetic evaluation in the beef industry are complex. Alternative prediction methods have been developed, either using multitrait models (Swan and Kinghorn, 1992) treating performance in each breed of dam as a different trait, as was done in this study, or fitting sire $x$ breed of dam interaction directly in the model (Elzo and Famula, 1985). As acknowledged by Swan and Meyer (1991), more information about estimates of correlations between purebreds and crosses or between crosses from different dam breeds is required before considering prediction procedures including sire $\times$ breed of dam interactions in the model.

\section{Implications}

Progeny data from sires of various breeds mated to different breeds of dams can be used to evaluate the importance of sire $\times$ breed of dam interaction. Results from this study indicate that ranking of sires producing purebreds or crosses, or crossbred calves from 
different breeds of dams, is approximately the same for birth and yearling weight, but some reranking might occur for weaning weight. Consideration of these interactions in genetic evaluations allows prediction of breeding values of sires producing progeny under a particular maternal environment.

\section{Literature Cited}

AAA. 1991. Spring Sire Evaluation Report. American Angus Association, St. Joseph, MO.

APHA. 1991. Polled Hereford Sire Summary. American Polled Hereford Association, Kansas City, MO.

Bertrand, J. K., and L. L. Benyshek. 1987. Variance and covariance estimates for maternally influenced beef growth traits. J. Anim. Sci. 64:728.

Boldman, K. G., and L. D. Van Vleck. 1991. Derivative-free restricted maximum likelihood estimation in animal models with a sparse matrix solver. J. Dairy Sci. 74:4337.

Brown, C. J., Z. B. Johnson, and D. W. Wright. 1990. Pre- and postnatal direct and maternal additive genetic influences on preweaning growth traits of beef calves. In: W. C. Hill, R. Thompson, and J. A. Woolliams (Ed.) Proc. 4th World Congr. Genet. Appl. Livest. Prod. 15:267.

Cundiff, L. V., K. E. Gregory, R. M. Koch, and G. E. Dickerson. 1986. Genetic diversity among cattle breeds and its use to increase beef production efficiency in a temperate environment. Proc. 3rd World Congr. Genet. Appl. Livest. Prod. 9:271.

Cundiff, L. V., R. M. Koch, and K. E. Gregory. 1984. Characterization of biological types of cattle (Cycle III). IV. Postweaning growth and feed efficiency. J. Anim. Sci. 58:312.

Cundiff, L. V., R. M. Koch, K. E. Gregory, and G. M. Smith. 1981. Characterization of biological types of cattle-Cycle II. IV. Postweaning growth and feed efficiency of steers. J. Anim. Sci. 53: 332.

Dunn, R. J., W. T. Magee, K. E. Gregory, L. V. Cundiff, and R. M. Koch. 1970. Genetic parameters in straightbred and crossbred beef cattle. J. Anim. Sci. 31:656.

Elzo, M. A., and T. R. Famula. 1985. Multibreed sire evaluation procedures within a country. J. Anim. Sci. 60:942.

Falconer, D. S. 1952. The problem of environment and selection. Am. Nat. 86:293.

Garrick, D. J., E. J. Pollak, R. L. Quaas, and L. D. Van Vleck. 1989. Variance heterogeneity in direct and maternal weight traits by sex and percent purebred for Simmental-sired calves. J. Anim. Sci. 67:2515.

George, A., J. Liu, and E. Ng. 1980. User guide for SPARSPAK: Waterloo sparse linear equations package. CS-78-30, Dept. Computer Sci., Univ. of Waterloo, Waterloo, Canada.

Gregory, K. E., L. V. Cundiff, G. M. Smith, D. B. Laster, and H. A. Fitzhugh, Jr. 1978. Characterization of biological types of cattle-Cycle II: I. Birth and weaning traits. J. Anim. Sci. 47: 1022 .

Gregory, K. E., D. B. Laster, L. V. Cundiff, G. M. Smith, and R. M. Koch. 1979a. Characterization of biological types of cattle-Cycle III: II. Growth rate and puberty in females. J. Anim. Sci. 49:461.

Gregory, K. E., G. M. Smith, L. V. Cundiff, R. M. Koch, and D. B. Laster $1979 \mathrm{~b}$. Characterization of biological types of cattle-Cycle III: I. Birth and weaning traits. J. Anim. Sci. 48: 271.

James, J. W. 1991. Effect of using an incorrect model in animal model REML estimation of heritability. In: Proc. 9th Conf. "Genetics for Profit and Prophets for Genetics" of Aust. Assoc. Anim. Breed. Genet. pp 477-479. Melbourne, Victoria.

Kinghorn, B. 1982. Genetic effects in crossbreeding. II. Multibreed selection indices. Z. Tierz. Zuechtungsbiol. 99:315.

Koch, R. M. 1972. The role of maternal effects in animal breeding: VI. Maternal effects in beef cattle. J. Anim. Sci. 35:1316.

Koger, M., A. F. Jilek, W. C. Burns, and J. R. Crockett. 1975. Sire effects for specific combining ability in purebred and crossbred cattle. J. Anim. Sci. 40:230.

Kriese, L. A., J. K. Bertrand, and L. L. Benyshek. 1991. Age adjustment factors, heritabilities and genetic correlations for scrotal circumference and related growth traits in Hereford and Brangus bulls. J. Anim. Sci. 69:478.

Laster, D. B., G. M. Smith, L. V. Cundiff, and K. E. Gregory. 1979. Characterization of biological types of cattle (Cycle II). II. Postweaning growth and puberty of heifers. J. Anim. Sci. 48: 500.

Laster, D. B., G. M. Smith, and K. E. Gregory. Characterization of biological types of cattle. IV. Postweaning growth and puberty of heifers. J. Anim. Sci. 43:63.

Long, C. R. 1980. Crossbreeding for beef production: Experimental results. J. Anim. Sci. 51:1197.

Massey, M. E., and L. L. Benyshek. 1981. Interactions involving sires, breed of dam and age of dam for performance characteristics in Limousin cattle. J. Anim. Sci. 53:940.

Meyer, K. 1989. Restricted maximum likelihood to estimate variance components for animal models with several random effects using a derivative-free algorithm. Genet. Sel. Evol. 21:317.

Meyer, K. 1991. Estimating variances and covariances for multivariate animal models by restricted maximum likelihood. Genet. Sel. Evol. 23:67.

Meyer, K., K. Hammond, M. J. Mackinnon, and P. F. Parnell. 1991. Modelling direct and maternal effects for growth traits in beef cattle. In: Proc. 9th Conf. "Genetics for Profit and Prophets for Genetics" of Aust. Assoc. Anim. Breed. Genet. pp 212-215. Melbourne, Victoria.

Mrode, R. A., and R. Thompson. 1990. Genetic parameters for body weight in beef cattle in Britain. In: W. C. Hill, R. Thompson, and J. A. Woolliams (Ed.). In: Proc. of the 4th World Congr. Genet. Appl. Livest. Prod. 15:271.

Nelder, J. A., and R. Mead. 1965. A simplex method for function minimization. Comput. J. 7:308.

Notter, D. R. 1989. EPD for use across breeds. 21st Mtg. Beef Improvement Fed. p 63. Nashville, TN.

Rao, C. R. 1972. Estimation of variance and covariance components in linear models. J. Am. Stat. Assoc. 67:112.

Robertson, A. 1959. The sampling variance of the genetic correlation coefficient. Biometrics 15:469.

Searle, S. R. 1979. Notes on variance component estimation. Cornell Univ., Ithaca, NY (Mimeo).

Searle, S. R. 1982. Matrix Algebra Useful for Statistics. John Wiley \& Sons, New York.

Smith, G. M., D. B. Laster, L. V. Cundiff, and K. E. Gregory. 1976a. Characterization of biological types of cattle. II. Postweaning growth and feed efficiency of steers. J. Anim. Sci. 43:37.

Smith, G. M., D. B. Laster, and K. E. Gregory. 1976b. Characterization of biological types of cattle. I. Dystocia and preweaning growth. J. Anim. Sci. 43:27.

Swan, A. A., and B. P. Kinghorn. 1992. Evaluation and exploitation of crossbreeding in dairy cattle. J. Dairy Sci. 75:624.

Swan, A. A., and K. Meyer. 1991. Prediction and estimation of nonadditive genetic effects within and across breeds. In: Proc. 9th Conf. "Genetics for Profit and Prophets for Genetics" of Aust. Assoc. Anim. Breed. Genet. pp 488-495. Melbourne, Victoria.

Tilsch, K., J. Wollert, and A. Baumung. 1989. Relationships between breeding values for growth of beef sires in purebreeding and crossbreeding. Livest. Prod. Sci. 21:275.

Wei, M., and H.A.M. van der Steen. 1991. Comparison of reciprocal recurrent selection with pure-line selection systems in animal breeding (A review). Anim. Breed. Abstr. 59:281.

Woldehawariat, G., M. A. Talamantes, R. R. Petty, and T. C. Cartwright. 1977. A summary of genetic and environmental statistics for growth and conformation characters of young beef cattle (2nd Ed.). Texas Agric. Exp. Sta. Dept. Tech. Rep. No. 103.

Wyatt, W. E., and D. E. Franke. 1986. Estimation of direct and maternal additive and heterotic effects for preweaning growth traits in cattle breeds represented in the Southern region. Southern Cooperative Ser., Bull. No. 310. Louisiana State Univ., Baton Rouge. 


\section{APPENDIX}

Assume the correct model is

$$
\mathbf{y}=\mathbf{X b}+\mathbf{Z}_{1} \mathbf{u}_{1}+\mathbf{Z}_{2} \mathbf{u}_{2}+\mathbf{Z}_{3} \mathbf{u}_{3}+\mathbf{e}
$$

with $\mathbf{E}[\mathbf{y}]=\mathbf{X b}$, and

$$
\begin{aligned}
\operatorname{Var}(\mathbf{y})= & \mathbf{Z}_{1} \mathbf{A}_{1} \mathbf{Z}_{1}{ }^{\prime} \sigma_{1}^{2}+\mathbf{Z}_{2} \mathbf{A}_{2} \mathbf{Z}_{2}{ }^{\prime} \sigma_{2}^{2}+\left(\mathbf{Z}_{1} \mathbf{A}_{12} \mathbf{Z}_{2}{ }^{\prime}\right. \\
& \left.+\mathbf{Z}_{2} \mathbf{A}_{12} \mathbf{Z}_{1}^{\prime}\right) \sigma_{12}+\mathbf{Z}_{3} \mathbf{Z}_{3}{ }^{\prime} \sigma_{3}^{2}+\mathbf{I} \sigma_{0}^{2}
\end{aligned}
$$

and that the model used for analysis is

$$
\mathbf{y}=\mathbf{X b}+\mathbf{Z}_{1} \mathbf{u}_{1}+\mathbf{Z}_{3} \mathbf{u}_{3}+\mathbf{e}
$$

with $\mathbf{E}[\mathbf{y}]=\mathbf{X b}$, and

$$
\operatorname{Var}(\mathbf{y})=\mathbf{Z}_{1} \mathbf{A}_{1} \mathbf{Z}_{1}^{\prime} \sigma_{1}^{2}+\mathbf{Z}_{3} \mathbf{Z}_{3}^{\prime} \sigma_{3}^{2}+\mathbf{I} \sigma_{0}^{2}
$$

where the subscripts indicate direct genetic effects (1), maternal genetic effects (2), permanent environmental effects (3), and residual effects $(0)$.

Sampling theory of REML estimation is not welldeveloped (James, 1991). However, expectations and variances of quadratic estimators such as MINQUE (Rao, 1972) are simple applications of the rules to obtain means and variances of quadratic forms (Searle, 1982). Iterative MINQUE under normality, if convergence is within the parameter space, equals REML estimators, providing the starting values for both procedures are the same (Searle, 1979). Also, a MINQUE estimator is equal to a first iterate solution of REML. Considering the relationship between REML and MINQUE estimators, the expectation of MINQUE estimators was obtained. Using $w_{0}, w_{1}$, and $\mathrm{w}_{3}$ as weights or "operational values" for $\sigma_{0}^{2}, \sigma_{1}^{2}$, and $\sigma_{3}^{2}$, respectively, the MINQUE equations are as follows:

$$
\left[\begin{array}{ccc}
\mathrm{T}_{11} & \mathrm{~T}_{13} & \mathrm{~T}_{10} \\
\mathrm{~T}_{13} & \mathrm{~T}_{33} & \mathrm{~T}_{30} \\
\mathrm{~T}_{10} & \mathrm{~T}_{30} & \mathrm{~T}_{00}
\end{array}\right]\left[\begin{array}{c}
\hat{\sigma}_{1}^{2} \\
\hat{\sigma}_{3}^{2} \\
\hat{\sigma}_{0}^{2}
\end{array}\right]=\left[\begin{array}{l}
\mathrm{q}_{1} \\
\mathrm{q}_{3} \\
\mathrm{q}_{0}
\end{array}\right]
$$

or

$$
\mathbf{T} \hat{\boldsymbol{\sigma}}=\mathbf{q}
$$

where $\mathrm{T}_{11}=\operatorname{tr}\left(\mathbf{P} \mathbf{Z}_{1} \mathbf{A}_{1} \mathbf{Z}_{1}{ }^{\prime} \mathbf{P} \mathbf{Z}_{1} \mathbf{A}_{1} \mathbf{Z}_{1}{ }^{\prime}\right), \quad \mathrm{T}_{13}=$ $\operatorname{tr}\left(\mathbf{P} \mathbf{Z}_{1} \mathbf{A}_{1} \mathbf{Z}_{1}^{\prime} \mathbf{P} \mathbf{Z}_{3} \mathbf{Z}_{3}{ }^{\prime}\right), \quad \mathrm{T}_{10}=\operatorname{tr}\left(\mathbf{P} \mathbf{Z}_{1} \mathbf{A}_{1} \mathbf{Z}_{1}{ }^{\prime} \mathbf{P}\right), \quad \mathrm{T}_{33}=$ $\operatorname{tr}\left(\mathbf{P} \mathbf{Z}_{3} \mathbf{Z}_{3}{ }^{\prime} \mathbf{P} \mathbf{Z}_{3} \mathbf{Z}_{3}{ }^{\prime}\right), \mathrm{T}_{30}=\operatorname{tr}\left(\mathbf{P} \mathbf{Z}_{3} \mathbf{Z}_{3} \mathbf{P}\right), \mathrm{T}_{00}=\operatorname{tr}(\mathbf{P P})$, $\mathrm{q}_{1}=\mathrm{y}^{\prime} \mathrm{PZ} \mathrm{Z}_{1} \mathrm{~A}_{1} \mathrm{Z}_{1}{ }^{\prime} \mathrm{Py}, \mathrm{q}_{3}=\mathrm{y}^{\prime} \mathrm{PZ}_{3} \mathrm{Z}_{3}{ }^{\prime} \mathrm{Py}, \mathrm{q}_{0}=\mathrm{y}^{\prime} \mathrm{PPy}, \mathbf{P}=$ $\mathbf{W}^{-1}-\mathbf{W}^{-1} \mathbf{X}\left(\mathbf{X}^{\prime} \mathbf{W}^{-1} \mathbf{X}\right)^{-1} \mathbf{X}^{\prime} \mathbf{W}^{-1}$, and $\mathbf{W}=\mathbf{Z}_{1} \mathbf{A}_{1} \mathbf{Z}_{1}^{\prime} \mathbf{w}_{1}+$ $\mathbf{Z}_{3} \mathbf{Z}_{3}^{\prime} \mathbf{w}_{3}+\mathbf{I} \mathbf{w}_{0}$.

Then, estimates of variance components are obtained from

$$
\hat{\boldsymbol{\sigma}}=\mathbf{T}^{-1} \mathbf{q}
$$

where

$$
\mathbf{T}^{-1}=\left[\begin{array}{lll}
\mathrm{T}_{33} \mathrm{~T}_{00}-\mathrm{T}_{30} \mathrm{~T}_{30} & \mathrm{~T}_{10} \mathrm{~T}_{30}-\mathrm{T}_{13} \mathrm{~T}_{00} & \mathrm{~T}_{13} \mathrm{~T}_{30}-\mathrm{T}_{10} \mathrm{~T}_{33} \\
\mathrm{~T}_{30} \mathrm{~T}_{10}-\mathrm{T}_{13} \mathrm{~T}_{00} & \mathrm{~T}_{11} \mathrm{~T}_{00}-\mathrm{T}_{10} \mathrm{~T}_{10} & \mathrm{~T}_{10} \mathrm{~T}_{13}-\mathrm{T}_{11} \mathrm{~T}_{30} \\
\mathrm{~T}_{13} \mathrm{~T}_{30}-\mathrm{T}_{33} \mathrm{~T}_{10} & \mathrm{~T}_{13} \mathrm{~T}_{10}-\mathrm{T}_{11} \mathrm{~T}_{30} & \mathrm{~T}_{11} \mathrm{~T}_{33}-\mathrm{T}_{13} \mathrm{~T}_{13}
\end{array}\right] \mathrm{D}
$$

with

$$
\begin{aligned}
\mathrm{D}= & \mathrm{T}_{11} \mathrm{~T}_{33} \mathrm{~T}_{00}+\mathrm{T}_{13} \mathrm{~T}_{30} \mathrm{~T}_{10}+\mathrm{T}_{10} \mathrm{~T}_{13} \mathrm{~T}_{30}-\mathrm{T}_{11} \mathrm{~T}_{30} \mathrm{~T}_{30} \\
& -\mathrm{T}_{13} \mathrm{~T}_{13} \mathrm{~T}_{00}-\mathrm{T}_{10} \mathrm{~T}_{10} \mathrm{~T}_{33},
\end{aligned}
$$

Then

$$
\mathrm{E}[\hat{\boldsymbol{\sigma}}]=\mathbf{T}^{-1} \mathrm{E}[\mathbf{q}]
$$

so that the expectations of the variance component estimates are as follows:

$$
\begin{aligned}
& \mathrm{E}\left[\hat{\sigma}_{1}^{2}\right]=\sigma_{1}^{2}+\left[\left(\mathrm{T}_{00} \mathbf{T}_{33}-\mathrm{T}_{30} \mathrm{~T}_{30}\right) \operatorname{tr}\left(\mathbf{P} \mathbf{Z}_{1} \mathbf{A}_{1} \mathbf{Z}_{1} \mathbf{P Z}_{2} \mathbf{A}_{2} \mathbf{Z}_{2}^{\prime}\right)\right] \sigma_{2}^{2} / \mathrm{D} \\
& +\left[\left(\mathrm{T}_{10} \mathrm{~T}_{30}-\mathrm{T}_{13} \mathrm{~T}_{00}\right) \operatorname{tr}\left(\mathbf{P} \mathbf{Z}_{3} \mathbf{Z}_{3} \mathbf{P Z}_{2} \mathbf{A}_{2} \mathbf{Z}_{2}{ }^{\prime}\right)\right] \sigma_{2}^{2} / \mathrm{D} \\
& +\left[\left(\mathrm{T}_{13} \mathrm{~T}_{30}-\mathrm{T}_{10} \mathrm{~T}_{33}\right) \operatorname{tr}\left(\mathbf{P P Z} \mathbf{Z}_{2} \mathbf{A}_{2} \mathbf{Z}_{2}{ }^{\prime}\right)\right] \sigma_{2}^{2} \mathrm{D} \\
& +\left[\left(\mathrm{T}_{00} \mathrm{~T}_{33}-\mathrm{T}_{30} \mathbf{T}_{30}\right) 2 \operatorname{tr}\left(\mathbf{P Z}_{1} \mathbf{A}_{1} \mathbf{Z}_{1}{ }^{\prime} \mathbf{P Z} \mathbf{Z}_{1} \mathbf{A}_{12} \mathbf{Z}_{2}{ }^{\prime}\right)\right] \sigma_{12} / \mathrm{D} \\
& +\left[\left(\mathrm{T}_{10} \mathbf{T}_{30}-\mathrm{T}_{13} \mathbf{T}_{00}\right) 2 \operatorname{tr}\left(\mathbf{P} \mathbf{Z}_{3} \mathbf{Z}_{3}{ }^{\prime} \mathbf{P} \mathbf{Z}_{1} \mathbf{A}_{12} \mathbf{Z}_{2}{ }^{\prime}\right)\right] \sigma_{12} / \mathrm{D} \\
& +\left[\left(\mathrm{T}_{13} \mathrm{~T}_{30}-\mathrm{T}_{10} \mathrm{~T}_{33}\right) 2 \operatorname{tr}\left(\mathbf{P P Z} \mathbf{Z}_{12} \mathbf{A}_{12} \mathbf{Z}_{2}^{\prime}\right)\right] \sigma_{12} / \mathrm{D} \\
& \mathrm{E}\left[\hat{\sigma}_{3}^{2}\right]=\sigma_{3}^{2}+\left[\left(\mathrm{T}_{30} \mathrm{~T}_{10}-\mathrm{T}_{13} \mathrm{~T}_{00}\right) \operatorname{tr}\left(\mathbf{P} \mathbf{Z}_{1} \mathbf{A}_{1} \mathbf{Z}_{1}{ }^{\prime} \mathbf{P} \mathbf{Z}_{2} \mathbf{A}_{2} \mathbf{Z}_{2}{ }^{\prime}\right)\right] \sigma_{2}^{2} / \mathrm{D} \\
& +\left[\left(\mathrm{T}_{11} \mathrm{~T}_{00}-\mathrm{T}_{10} \mathrm{~T}_{10}\right) \operatorname{tr}\left(\mathbf{P} \mathbf{Z}_{3} \mathbf{Z}_{3}{ }^{\prime} \mathbf{P} \mathbf{Z}_{2} \mathbf{A}_{2} \mathbf{Z}_{2}{ }^{\prime}\right)\right] \quad \sigma_{2}^{2} / \mathrm{D} \\
& +\left[\left(\mathbf{T}_{10} \mathrm{~T}_{13}-\mathrm{T}_{11} \mathrm{~T}_{30}\right) \operatorname{tr}\left(\mathbf{P} \mathbf{P} \mathbf{Z}_{2} \mathbf{A}_{2} \mathbf{Z}_{2}{ }^{\prime}\right)\right] \sigma_{2}^{2} / \mathrm{D} \\
& +\left[\left(\mathbf{T}_{30} \mathrm{~T}_{10}-\mathrm{T}_{13} \mathrm{~T}_{00}\right) 2 \operatorname{tr}\left(\mathbf{P Z} \mathbf{Z}_{1} \mathbf{A}_{1} \mathbf{Z}_{1}{ }^{\prime} \mathbf{P} \mathbf{Z}_{1} \mathbf{A}_{12} \mathbf{Z}_{2}{ }^{\prime}\right)\right] \sigma_{12} / \mathrm{D} \\
& +\left[\left(\mathbf{T}_{11} \mathbf{T}_{00}-\mathbf{T}_{10} \mathbf{T}_{10}\right) 2 \operatorname{tr}\left(\mathbf{P} \mathbf{Z}_{3} \mathbf{Z}_{3}{ }^{\prime} \mathbf{P} \mathbf{Z}_{1} \mathbf{A}_{12} \mathbf{Z}_{2}{ }^{\prime}\right)\right] \sigma_{12} / \mathbf{D}
\end{aligned}
$$

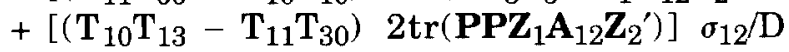




$$
\begin{aligned}
& \mathrm{E}\left[\hat{\boldsymbol{\sigma}}_{0}^{2}\right]=\sigma_{0}^{2}+\left[\left(\mathrm{T}_{13} \mathrm{~T}_{30}-\mathrm{T}_{33} \mathrm{~T}_{10}\right) \operatorname{tr}\left(\mathbf{P} \mathbf{Z}_{1} \mathbf{A}_{1} \mathbf{Z}_{1}{ }^{\prime} \mathbf{P} \mathbf{Z}_{2} \mathbf{A}_{2} \mathbf{Z}_{2}{ }^{\prime}\right)\right] \sigma_{2}^{2} / \mathrm{D} \\
& +\left[\left(\mathrm{T}_{13} \mathrm{~T}_{10}-\mathrm{T}_{11} \mathrm{~T}_{30}\right) \operatorname{tr}\left(\mathbf{P} \mathbf{Z}_{3} \mathbf{Z}_{3} \mathbf{P Z}_{2} \mathbf{A}_{2} \mathbf{Z}_{2}{ }^{\prime}\right)\right] \sigma_{2}^{2} / \mathrm{D} \\
& +\left[\left(\mathrm{T}_{11} \mathbf{T}_{33}-\mathrm{T}_{13} \mathrm{~T}_{13}\right) \operatorname{tr}\left(\mathbf{P} \mathbf{P} \mathbf{Z}_{2} \mathbf{A}_{2} \mathbf{Z}_{2}{ }^{\prime}\right)\right] \sigma_{2}^{2} / \mathrm{D} \\
& +\left[\left(\mathrm{T}_{13} \mathrm{~T}_{30}-\mathrm{T}_{33} \mathrm{~T}_{10}\right) 2 \operatorname{tr}\left(\mathbf{P Z}_{1} \mathbf{A}_{1} \mathbf{Z}_{1} \mathbf{P Z}_{1} \mathbf{A}_{12} \mathbf{Z}_{2}{ }^{\prime}\right)\right] \sigma_{12} / \mathrm{D} \\
& +\left[\left(\mathrm{T}_{13} \mathrm{~T}_{10}-\mathrm{T}_{11} \mathrm{~T}_{30}\right) 2 \operatorname{tr}\left(\mathbf{P} \mathbf{Z}_{3} \mathbf{Z}_{3} \mathbf{P Z}_{1} \mathbf{A}_{12} \mathbf{Z}_{2}{ }^{\prime}\right)\right] \sigma_{12} / \mathrm{D} \\
& +\left[\left(\mathrm{T}_{11} \mathrm{~T}_{33}-\mathrm{T}_{13} \mathrm{~T}_{13}\right) 2 \operatorname{tr}\left(\mathbf{P P Z} \mathbf{A}_{12} \mathbf{Z}_{2}^{\prime}\right)\right] \sigma_{12 / \mathrm{D}}
\end{aligned}
$$

Because $\mathbf{Z}_{1}=\mathbf{I}, \mathbf{Z}_{2}=\mathbf{Z}_{3}$, and if dams are unrelated $\left(\mathbf{A}_{2}=\mathbf{I}\right)$, the estimated variances of maternal genetic effects $\left(\sigma_{2}^{2}\right.$ ) will be completely confounded with the variance of permanent environmental effects $\left(\sigma_{3}^{2}\right)$.
The degree of confounding of the covariance between direct and maternal genetic effects $\left(\sigma_{12}\right)$ with the different variance component estimates will depend on the degree of relationships between calves and cows $\left(\mathbf{A}_{12}\right)$. 